\title{
Social Networks Apps and their Role in Tourism Marketing in the Kingdom of Saudi Arabia
}

\author{
https://doi.org/10.3991/ijim.v15i20.23743 \\ Nabil Mohemmed Al-Hazmi ${ }^{(凶)}$ \\ Prince Sattam bin Abdulaziz University-Kingdom, Al-Kharj, Saudi Arabia \\ n.alhazmi@psau.edu.sa
}

\begin{abstract}
This study aimed at investigating the role of social networks apps in tourism marketing for travel and tourism organizations in Al-Kharj City, Kingdom of Saudi Arabia. The study used the descriptive and analytical approach to achieve its objectives and test its hypothesis. The study found that social networks apps play a vital role in marketing the tourism product in Al-Kharj City as well as communicating effectively and cheaply with the customers. The study recommended nominating and training some workers in tourism organizations to deal with social media networks and design websites and applications for these organizations.
\end{abstract}

Keywords—-social networks apps, mobile, tourism marketing, tourism organization

\section{$1 \quad$ Introduction}

Marketing through social networks apps is regarded as an influential tool to get potential customers for all businesses of any sizes. Customers interact with brands through these platforms. Social networks apps marketing is a form of internet marketing, which includes creating and sharing the content on social media platforms to achieve marketing objectives and the brand names. Social media marketing contains activities such as posting updates, photos, videos, and other content, which encourages audience's participation. In addition to paid advertisements to platforms to reach customers in automatically without the constant need to update or publish the content manually. Social networks apps, allow individuals to interact with each other and build social relationships on the Internet [11]. When a prominent channel joins a social networking site, this provides it with a great possibility to directly communicate with its audience around the world. This makes it easier for them to promote their products rather than what they will exhibit and guarantee reaching a big number of followers. There is a very significant feature, which makes social networking sites one of the most efficient means of marketing, which is the feature of "sharing" or "retweeting" the posts that the marketer issues if the customer is interested in this post. This allows the marketer's message to spread widely in a short time if these sites are used accurately. Social media 
also contains a great deal of information about services or products, which potential customers may desire to have. This gives the ability to easily analyze the market, reach customer's desires, and target them through the product being marketed. The current development of social networks has had a direct and clear impact on different fields and business sectors in general and on tourism and travel organizations in particular [12]. Activities and means have changed from being slow and needs a large numbers of human resource to faster and more precise and do not need human resources because they are automated. Marketing, either goods or services, has witnessed a great development in light of social media networks in terms of product presentation, specifications, prices, and even the way of delivering it to the customer in a short time, reducing efforts and cost. Considering that tourism and travel organizations are one of the commercial institutions aiming at achieving profits and reducing the costs to the possible range to display their services, tourism programs and offers, especially on occasions and holidays, they must take advantage of social networks apps to communicate with their customers directly. Travel and tourism organizations in the Kingdom began to use social networks apps as a marketing tool for their different tourism services and programs.

\subsection{Study problem}

The study problem is based on the following questions:

1. Do the operating travel and tourism organizations in Al-Kharj use social networks apps to market their tourism programs? What are the most used social networks apps by travel and tourism organizations?

2. Do social networks apps have an impact on marketing tourism services? Did social networks apps contribute to increase the number of customers who deal with tourism organizations?

\subsection{Study significance}

The study significance is represented in the following:

1. Clarifying the significance of social networks apps in E-marketing for tourism organizations in Al-Kharj City, as well as decreasing marketing costs represented by decreasing effort and time in marketing tourism products.

2. Highlighting the most widely used social networks apps in online tourism marketing for services.

\subsection{Study objectives}

This study seeks to achieve the following objectives:

1. Identifying the extent of social networks apps use in tourism companies in Al- Kharj city.

2. Identifying the impact of social networks apps on marketing tourism services. 


\subsection{Study hypothesis}

The study seeks to test the following hypothesis:

There is a significant correlation between social networks apps and marketing tourism product in travel and tourism organizations in Al-Kharj city.

\subsection{Study population and sample}

The study population is represented by all the operating tourism and travel organizations in Al-Kharj city, which number 16 companies. The study sample was randomly selected from workers in these organizations. The study sample reached 60 workers from travel and tourism organizations in Al-Kharj city.

\subsection{Study methodology}

The study is based on the descriptive and analytical approach by collecting secondary data from books, Master's \& PhDs Theses, researches and periodicals, and collecting primary data by preparing a questionnaire to collect the opinions of the sample respondents. In addition, the five-year Likart scale was used (strongly disagreedisagree-neutral-agree-agree strongly).

\subsection{Study tool}

A questionnaire was designed including the study variables and it was distributed to the study sample based on [6]. The questionnaire contains two parts, a part for social networks apps, and a part for marketing the tourism product. In order to test the internal consistency of the questionnaire, it has been presented to a number of specialists at Prince Sattam bin Abdulaziz University, King Abdulaziz University and Taiz University. To test the stability of the questionnaire paragraphs, the alpha correlation coefficient (Cronbach's alpha coefficient) was used. The social media axis reached (0.875), and marketing the tourism product axis reached (0.916), and for the scale in general reached (0.896). Table 1 represents Stability coefficient, alpha cronbach of the study tool.

Table 1. Stability coefficient, alpha cronbach of the study

\begin{tabular}{|l|l|c|c|}
\hline \multicolumn{1}{|c|}{ No. } & \multicolumn{1}{c|}{ Study Variables } & Paragraphs & Cronbach's Coefficient Alpha \\
\hline 1 & Social Networks & 8 & 0.875 \\
\hline 2 & Tourist Product & 4 & 0.916 \\
\hline Total & & 12 & 0.896 \\
\hline
\end{tabular}

\subsection{Study limitations}

Objective limitations: This study seeks to investigate the issue of the relationship between social networks apps and the marketing of tourism products in the Kingdom of Saudi Arabia. 
Time limitations: This study was conducted in the period from 1-9-2020 to 12-31-2020

Human limitations: This study was conducted on workers in travel and tourism organizations in Al-Kharj city.

\section{Literature review}

There are few related studies to the topic of this study. Among which is; the study [6] which aimed at studying the impact of social networks on marketing the tourism products in Iraq. The study recommended the necessity to use social media sites to attract customers, serve them better, and nominate staff to deal with these sites. The study $[3,4]$ recommended the importance of using social media networks to communicate with customers in tourism and travel organizations in Al-Kharj to ensure fast communication with them and meet their desires. While the study [1] recommended the importance of marketing via social media networks. The study [12] recommended studying the importance of managing the relationship with customers to achieve their satisfaction in travel and tourism organizations. The study also recommended the necessity to communicate with customers using modern technologies and social media. The study [12] aimed at studying the importance of managing the relationship with customers to achieve their satisfaction in travel and tourism organizations. The study also recommended the necessity to communicate with customers using modern technologies and social media. The study [10] aimed at determining the role of social networking sites in the marketing of handicrafts. It also recommended the necessity to use social media sites intensively in marketing handicrafts. The study [8] recommended the importance of using social media sites to market the products of modern organizations. The study [2] recommended the importance of using social networks and websites in marketing tourism products and training workers in dealing with these networks. The study [9] aimed at studying the importance of social networks in determining customers' purchasing decision, and recommended the organizations to activate using social networks to market their products. The study [5] recommended the importance that the companies should adopt social media in their business, especially in the field of marketing and focusing their efforts on improving the efficiency of their content on social media. The study [7] aimed at studying the role of social media in supporting marketing communication. In addition, the study recommended using social networks due to their role in supporting marketing communication with customers and gaining their loyalty to the organization.

Through reviewing the previous studies, we find that most of them dealt with different topics and were conducted in rather different areas. Hence, this study is distinguished from other previous studies that were conducted on travel and tourism organizations in Al Kharj Governorate. Moreover, this study addressed the topic of social networks and their role in tourism marketing in Saudi Arabia. 


\section{Analytical side}

The questionnaire was distributed to the study sample individuals from the travel and tourism companies in Al-Kharj city.

\subsection{Results of the descriptive statistical analysis of the characteristics of the individuals of the study sample}

According to the gender, the samples are distributed as shown in Table 2. According to age, the samples are distributed as shown in Table 3.

Table 2. Distribution of the sample items according to gender

\begin{tabular}{|l|c|c|}
\hline \multicolumn{1}{|c|}{ Sex } & Repetition & Percentage 100\% \\
\hline Male & 44 & 73.333 \\
\hline female & 16 & 26.666 \\
\hline Total & 60 & 100 \\
\hline
\end{tabular}

We notice from the previous table that $(73.333 \%)$ of the sample were males, and $(26.666 \%)$ were females.

Table 3. Distribution of the sample individuals according to age

\begin{tabular}{|l|c|c|}
\hline \multicolumn{1}{|c|}{ Age } & Repetition & Percentage 100\% \\
\hline Less than 20 years & 16 & 26.666 \\
\hline From 21 to 30 years & 10 & 16.667 \\
\hline From 31 to 40 years & 15 & 25.000 \\
\hline From 41 to 50 years & 10 & 16.667 \\
\hline Greater than 51years & 9 & 15.000 \\
\hline Total & 60 & 100.000 \\
\hline
\end{tabular}

From the previous table, we also noticed that most of the sample individuals were less than 20 years old (26.666\%). This indicates that most of the workers in travel and tourism organizations are of young ages, and the lowest percentage was for the age group 50 years and up, which reached (15\%).

Table 4. Distribution of the sample individuals according to experience

\begin{tabular}{|l|c|c|}
\hline \multicolumn{1}{|c|}{ Years of Experience } & Repetition & Percentage 100\% \\
\hline Less than 5 years & 35 & 58.333 \\
\hline From 6 to 10 & 13 & 21.667 \\
\hline From 11 to 15 & 7 & 11.667 \\
\hline More than 16 years & 5 & 08.333 \\
\hline Total & 60 & 100.000 \\
\hline
\end{tabular}


From the previous table, we noticed that most of the research sample individuals are less than 5 years' experience, which reached $(58.333 \%)$. This is consistent with the age characteristics of the study sample in Table 4, and the lowest category of work experience in travel and tourism organizations was more than 16 years, which reached $(08.333 \%)$. According to the academic qualification, the sample individuals are distributed as shown in Table 5 .

Table 5. Distribution of the sample individuals according to academic qualification

\begin{tabular}{|l|c|c|}
\hline \multicolumn{1}{|c|}{ Degree } & Repetition & Percentage 100\% \\
\hline Secondary & 35 & 58.333 \\
\hline Diploma & 13 & 21.667 \\
\hline Bachelor & 12 & 20.000 \\
\hline Total & 60 & 100 \\
\hline
\end{tabular}

From the previous table, we notice that most of the sample individuals are those who hold a high school certificate, which reached (58.333\%), and those who hold a diploma certificate reached $(21.667 \%)$, compared with those with a bachelor's degree, which reached $(20 \%)$.

\subsection{The results of the analysis for the response of the study sample individuals in the travel and tourism organizations in Al-Kharj city}

Table 6 represents the results of the statistical analysis of the independent variable social networks apps. Table 6 represents the results of the statistical analysis of the independent variable social networks apps.

Table 6. The results of the statistical analysis of the independent variable social networks apps

\begin{tabular}{|l|l|c|c|l|}
\hline No. & \multicolumn{1}{|c|}{ Paragraph } & Mean & St Dev. & Degree \\
\hline 1 & $\begin{array}{l}\text { The company has an official Twitter, Facebook and } \\
\text { Instagram account. }\end{array}$ & 4.539 & 0.891 & High \\
\hline 2 & $\begin{array}{l}\text { The company mainly depends on the marketing of } \\
\text { its services via social networks. }\end{array}$ & 3.674 & 0.778 & High \\
\hline 3 & $\begin{array}{l}\text { The company has employees whose main tasks } \\
\text { are to publish via social networks for the services } \\
\text { provided by it, flight schedules and departure slots. }\end{array}$ & 3.492 & 1.204 & High \\
\hline 4 & $\begin{array}{l}\text { The company's official website is periodically } \\
\text { updated to cope up with the latest developments } \\
\text { and technologies in this field. }\end{array}$ & 3.489 & 0.749 & High \\
\hline 5 & $\begin{array}{l}\text { The company has a special application via which } \\
\text { the customer can learn about the most important } \\
\text { services provided by it. }\end{array}$ & 3.210 & 1.003 & High \\
\hline 6 & $\begin{array}{l}\text { The company's employees have sufficient awareness } \\
\text { and knowledge about what social networks are. }\end{array}$ & 3.537 & 0.692 & High \\
\hline 7 & $\begin{array}{l}\text { The company has a big number of friends \& } \\
\text { followers of its social media account. }\end{array}$ & 3.720 & 0.789 & High \\
\hline Total & \begin{tabular}{l} 
3.587 \\
\hline
\end{tabular} & $\mathbf{0 . 7 9 9}$ & High \\
\hline
\end{tabular}


From the previous table, it is clear that the results of the statistical analysis of the related paragraphs of the questionnaire are the first variable (social networks apps); the paragraph with the highest value was the first paragraph with an arithmetic mean (4.539) and a standard deviation (0.891). This indicates that travel and tourism organizations in Al-Kharj have an official account on Twitter, Facebook, Instagram, and Telegram. Paragraph No. 5 was ranked the lowest with an arithmetic mean (3.210) and a standard deviation (0.692). This indicates that travel and tourism organizations in Al-Kharj have a special application through which the customer can be familiar with the most important services provided. The attitude of the study sample were positive towards all paragraphs, as the mean of all paragraphs reached (3.587), and the standard deviation for all paragraphs reached (0.799), and the response level that represents the sample's agreement and consistency. Table 7 represents the results of the statistical analysis of the variable (tourism product approved marketing).

Table 7. Results of the statistical analysis of the variable (tourism product approved marketing)

\begin{tabular}{|l|l|c|c|l|}
\hline No. & \multicolumn{1}{|c|}{ Paragraph } & Mean & St Dev. & Degree \\
\hline 1 & $\begin{array}{l}\text { Marketing the tourism product via social networks } \\
\text { has significantly increased profits in the company. }\end{array}$ & 3.952 & 0.862 & High \\
\hline 2 & $\begin{array}{l}\text { Marketing the tourism product via social networks } \\
\text { facilitates the process of communication between } \\
\text { the customer and the company. }\end{array}$ & 4.601 & 0.950 & High \\
\hline 3 & $\begin{array}{l}\text { Using social networks in marketing the tourism } \\
\text { product has improved the promotional process of } \\
\text { the services provided by the company. }\end{array}$ & 4.304 & 0.916 & High \\
\hline 4 & $\begin{array}{l}\text { Marketing the tourism product via social networks } \\
\text { has reduced the time needed to introduce the } \\
\text { customer to the tourism services and programs } \\
\text { provided by the company. }\end{array}$ & 3.896 & 0.904 & High \\
\hline 5 & $\begin{array}{l}\text { Marketing tourism products via social networks has } \\
\text { reduced the cost of marketing. }\end{array}$ & 3.708 & 0.869 & High \\
\hline 6 & $\begin{array}{l}\text { Marketing the tourism product via social networks } \\
\text { helped the company to build its brand name. }\end{array}$ & 3.754 & 0.872 & High \\
\hline Total & $\begin{array}{l}\text { Using social networks has contributed to increasing } \\
\text { the number of customers dealing with the company. }\end{array}$ & 3.697 & 0.859 & High \\
\hline
\end{tabular}

From the previous table, it shows the results of the statistical analysis of the questionnaire paragraphs which are related to the second variable (marketing the tourism product), the highest ranked paragraph was paragraph No.(2) with an arithmetic mean (4.601) with a standard deviation (0.950). This indicates that marketing the tourism product through social networks apps facilitates the contacting between the customer and the company. The lowest ranked paragraph was No. 7, with an arithmetic mean (3.697) and a standard deviation (0.859). This indicates that the use of social networks apps contributed to increase the number of customers dealing with the company. The attitudes of the study sample were positive towards all paragraphs, as the arithmetic mean of all paragraphs is (4.014) with standard deviation for all paragraphs is (0.897), and the response level represents the sample's agreement and consistency. 


\subsection{Testing the study hypothesis}

In order to measure or test the strength of the correlation between the study variables, the simple correlation coefficient (Pearson Correlation) was used, as Table 8 shows the simple correlation between the study variables (social networks apps s and tourism product marketing).

Table 8. Test the study hypothesis - simple correlation between the study variables

\begin{tabular}{|c|c|c|c|}
\hline \multicolumn{4}{|c|}{ Correlations } \\
\hline & & $\begin{array}{l}\mathrm{X} \text { (Marketing the } \\
\text { Tourism Product) }\end{array}$ & $\begin{array}{c}\text { Y( Social } \\
\text { Networks apps) }\end{array}$ \\
\hline \multirow{3}{*}{$\begin{array}{l}\text { X } \\
\text { (Marketing The } \\
\text { Tourism Product) }\end{array}$} & $\begin{array}{l}\text { Pearson } \\
\text { Correlation }\end{array}$ & 1 & -0.156 \\
\hline & Sig. (2-tailed) & & 0.000 \\
\hline & $\mathrm{N}$ & 60 & \\
\hline \multirow{3}{*}{$\begin{array}{l}\text { Y } \\
\text { (Social Networks } \\
\text { apps) }\end{array}$} & $\begin{array}{l}\text { Pearson } \\
\text { Correlation }\end{array}$ & -0.156 & 1 \\
\hline & Sig. (2-tailed) & 0.000 & \\
\hline & $\mathrm{N}$ & 60 & 60 \\
\hline
\end{tabular}

It is clear from the results in Table 8 that there is a negative correlation between social networks apps and the marketing of the tourism product and the type of this relationship is contrary. This leads us to accept the study hypothesis, which states; there is a significant correlation between social networks apps and tourism product marketing, and rejecting the alternative hypothesis, which states: There is no significant correlation between social networks apps and marketing of the tourism product.

\section{Conclusion}

Through analyzing the study results, we find that travel and tourism organizations in Al-Kharj city have an official account on Twitter, Facebook, Instagram, and Telegram, and heavily count on social networks apps to market their services. In addition, we find that marketing the tourism product through social networks apps has reduced the time required to familiarize the customer with tourism services and programs and facilitated the process of contacting customers and increasing their number. Consequently, it is important to excel and concentrate on the use of social networks apps and to develop their marketing activities for the purpose of benefiting and obtaining a competitive advantage. Also, to nominate an employee in every tourism organization, whose main task is to follow up and maintain the company's account on social networks apps and respond to customers' questions at the soonest time possible to facilitate contacting with the customer to win him, and to design special applications for the company to contact with customers and serve them better, which leads to save time, effort and cost. 


\section{$5 \quad$ Acknowledgment}

The researcher extends his sincere thanks to the Deanship of Scientific Research at Prince Sattam bin Abdulaziz University for its continuous support and contributions in the field of scientific research.

\section{References}

[1] Abonaser, S. (2020). Social networks and their role in achieving the effectiveness of electronic marketing for technical colleges Technology and Science Journal 2(2021), 247-252.

[2] Alajjal, A. (2019). The role of social networks in marketing tourism products. Journal of Strategy and Development, 6(4), 519-529.

[3] Alhazmi, N. (2020). The impact of customer relationship management on customer retention in travel and tourism organizations. Management Science Letters 11(2021), 247-252. https://doi.org/10.5267/j.msl.2020.8.009

[4] Alhazmi, N. (2020). Relationship Marketing \& Its Role in Enhancing Customer Satisfaction in Saudi Tourism Organizations. International Journal of Modern Agriculture, 9(4), $470-478$.

[5] Alnosoor, H. (2016). The Impact of Marketing Using Social Media on Buying Intentions in Jordan. Jordanian Journal of Business Administration, 12(3), 519-530. https://doi. org/10.12816/0033321

[6] Alshmerri, K. (2019). The impact of social networking sites on marketing the tourism product in Iraq. Journal of the Sebt, 5(5), 249-268.

[7] Ameerh, M. (2020). The Role of Social Media in increasing the efficiency of Communication. Journal of Financial and Economic Studies, 8(4), 621-635.

[8] Falak, M. (2017). The Role of Social Media in Contemporary Marketing. The Academy of Social and Human Studies, 8(2), 408-426.

[9] Khafallah, M. (2019). The impact of social media marketing on the consumer's buying decision. Journal of Management and Economics, 10(2), 213-226.

[10] Makhloof, A. (2019). The role of social media sites in marketing handmade products. Management Sciences Journal, 6(2), 231-246.

[11] Malek Alksasbeh, Mohammed Abuhelaleh, Mohammed Amin Almaiah, Mohamed AL-jaafreh, Anas Abu karaka. (2019). Towards a Model of Quality Features for Mobile Social Networks Apps in Learning Environments: An Extended Information System Success Model. International Journal of Interactive Mobile Technologies, 13(5), 75-93. https:// doi.org/10.3991/ijim.v13i05.9791

[12] Nabil Mohemmed Al-Hazmi. (2021). The Use of Mobile Phones and their Apps in Tourism Marketing in the Kingdom of Saudi Arabia. International Journal of Interactive Mobile Technologies, 15(6), 193-2021. https://doi.org/10.3991/ijim.v15i06.20635

\section{$7 \quad$ Author}

Dr. Nabil Mahemmed Al-Hazmi, Associate Professor of Marketing and Head of Marketing Department - College of Business Administration, Prince Sattam bin 
Abdulaziz University in the Kingdom of Saudi Arabia from 2015 until now, Professor of Tourism Marketing and Head of the Department of Tourism Management at Taiz University in the Republic of Yemen from 2008 to 2015. He published many research papers and studies in the field of tourism marketing in the Kingdom of Saudi Arabia and the Republic of Yemen. He has authored a set of books in the field of Marketing Management and Tourism Marketing. One of the trainers accredited by the International Finance Organization (IFC), a certified trainer at the International Labor Organization, and a member of the Board of Directors of the International Business License (IBDL).

Article submitted 2021-05-04. Resubmitted 2021-06-29. Final acceptance 2021-06-29. Final version published as submitted by the authors. 